\title{
IMPLIKASI YURIDIS PEMBERIAN GAJI KEPADA ORGAN YAYASAN DALAM PENGELOLAAN YAYASAN PENDIDIKAN
}

\author{
Ya' M. Irwansyah \\ Kantor Notaris Joko Sebastian, SH., M.Kn. \\ J1. Jendral Sudirman Blok E No. 1-2 Pontianak \\ Email: ya.irwansyah@gmail.com
}

\begin{abstract}
Foundation as one of the legal entity in Indonesia has existed before the enactment of Law Foundation Number 16 of 2001, on August 06 2001. The problems arising out of the enforcement of Law Foundation is the prohibition of salary to the foundation trustee as stated in Article 5 of Law Foundation and the imposition of sanctions for violations are set out in article 70 of Law Foundation. This journal uses empirical research methods to see the law in reality and examine the law in society. But the reality is the implementation is not yet fully achieved because there is no controlled of foundations from the outside. Especially with the provisions of Article 6 of Law Foundation, which provides opportunities for foundations trustee to get benefit, rather than as salary, but in the form of reimbursement of expenses that have been incurred so if it can be interpreted as a deviation to the article 5. The aim of this journal is to provide an overview of the implications of the existing regulations with the application in reality, especially foundations as providers of educational institutions so that it can be concluded that the prohibition prohibition against the granting of salary are basically not meet the elements of justice when viewed from the theory of justice and the rule of law, and contrary to the 1945 Constitution which has guaranteed the right of every citizen to obtain a job and obtain reasonable compensation on the job.
\end{abstract}

Key word: prohibition of salary, payment, honorarium, foundation

\begin{abstract}
Abstrak
Yayasan sebagai salah satu bentuk badan hukum di Indonesia telah didirikan sebelum diberlakukannya Undang-undang Yayasan Nomor 16 Tahun 2001 pada tanggal 06 Agustus 2001.Salah satu permasalahan yang timbul terhadap pemberlakuan Undang-undang Yayasan adalah adanya larangan pemberian gaji/ upah kepada organ yayasan sebagaimana tercantum pada Pasal 5 Perubahan Undang-undang Yayasan dan pengenaan sanksi atas pelanggaran tersebut diatur pada Pasal 70 Undang-undang Yayasan. Metode penelitian secaraempiris digunakan dalam jurnal ini yang untuk melihat hukum dalam artian nyata dan meneliti bagaimana bekerjanya hukum di lingkungan masyarakat.Namun pada kenyataan di keseharian, pelaksaannya belum sepenuhnya tercapai karena lemahnya pengawasan terhadap yayasan dari luar.Apalagi dengan adanya ketentuan pada Pasal 6 Undang-undang Yayasan yang memberikan peluang bagi organ yayasan untuk memperoleh manfaat, bukan sebagai gaji/ upah, namun berupa penggantian biaya yang telah dikeluarkan sehingga jika ditafsirkan dapat dijadikan sebagai penyimpangan terhadap Pasal 5 tersebut. Tujuan dalam penulisan jurnal ini untuk adalah memberikan gambaran mengenai implikasi antara peraturan yang telah ada dengan penerapan
\end{abstract}


dalam keseharian khususnya yayasan sebagai penyelenggara lembaga pendidikan sehingga dapat ditarik kesimpulan bahwa larangan terhadap pemberian gaji/ upah tersebut pada dasarnya belum memenuhi unsur keadilan jika dilihat dari teori keadilan dan kepastian hukum, serta bertentangan dengan konstitusi dimana UUD 1945 telah menjamin hak setiap warga negara untuk memperoleh pekerjaan dan memperoleh imbalan yang layak atas pekerjaannya tersebut.

Kata kunci: larangan gaji, upah, honorarium, yayasan

\section{Latar Belakang}

Istilah Yayasan telah dikenal oleh masyarakat di Indonesia jauh sebelum dibentuknya Undang-undang Yayasan pada tanggal 06 Agustus 2001, dimana pada saat itu pengakuan Yayasan sebagai badan hukum lebih didasarkan pada kebiasaan dan yurisprudensi (Putusan Mahkamah Agung tanggal 27 Juni 1973 No. 124/Sip/1973). Salah satu contoh yayasan yang ada sebelum adanya pemberlakuan Undang-undang Yayasan adalah Yayasan Dana Landreform yang dibentuk oleh Menteri Agraria sebagai pelaksanaan dari PP No. 224 Tahun 1961 pada tanggal 25 Agustus $1961^{1}$. Kemudian di tahun 1993 juga telah dibentuk Yayasan Dana Pensiun $^{2}$ melaluiKeputusan Menteri Keuangan RI Nomor 227/KMK.017/1993. Diantara sekian banyak peraturan di Indonesia, sedikit sekali peraturan yang menyinggung tentang yayasan, seperti yang terdapat pada Pasal 899, 900, 1680 dan Pasal 365 KUHPerdata, kemudian dalam Pasal 6 ayat (3) dan Pasal
$236 \mathrm{Rv}$ (Reglement of de Rechtsvordering ${ }^{3}$ ). Akan tetapi di dalam Pasal-Pasal tersebut tidak memberikan pengertian maupun aturan main yang jelas mengenai yayasan.

Motif dari masyarakat (pendiri) pada masa itu memilih yayasan sebagai badan hukum tidak terlepas dari kemudahan yang ditawarkan dalam pendirian sebuah yayasan, diantaranya 1.) proses pendirian yang sederhana, 2.) tanpa perlu adanya pengesahan dari pemerintah, serta 3.) adanya persepsi yang salah dari masyarakat yang mengartikan yayasan bukan sebagai subyek pajak, hal tersebut dikarenakan yayasan memiliki maksud dan tujuan yang bersifat sosial, dan memerankan fungsi kemasyarakatan sehingga oleh pemerintah diberikan insentif (keringanan) di bidang perpajakan, dan hal tersebut diatur dalam Pasal 4 ayat (3) butir (i) dan (j) Undangundang Republik Indonesia Nomor07 Tahun 1983 tentang Pajak Penghasilan. ${ }^{4}$

Dengan banyaknya pendirian yayasan di Indonesia tanpa aturan main yang jelas,

1 Boedi Harsono, Hukum Agraria Indonesia, Sejarah Pembentukan Undang-undang Pokok Agraria, Isi dan Pelaksanaannya, Jilid I Hukum Tanah Nasional, (Jakarta: Djambatan, 1994), hlm. 320.

2 A. Setiadi, Dana Pensiun Sebagai Badan Hukum, (Bandung: Citra Aditya Bakti, 1995), hlm. 241.

3 Hukum Acara Perdata yang berlaku bagi orang 'Eropa' dan 'Timur Asing' yang berada di Indonesia.

4 Bunyi lengkap Pasal (3): “Tidak termasuk sebagai Obyek Pajak adalah:

i penghasilan Yayasan dari usaha yang semata-mata ditujukan untuk kepentingan umum;

$\mathrm{j}$ penghasilan Yayasan dari modal sepanjang penghasilan itu semata-mata digunakan untuk kepentingan umum". 
serta banyaknya penyimpangan yang terjadi seperti pergeseran tujuan dasar yayasan dari badan hukum nirlaba menjadi badan hukum komersial, menimbulkan kekhawatiran bagi sebagian kalangan agar yayasan segera diberikan payung hukum. Atas dasar untuk mengisi kekosongan hukum dan untuk menata kembali peraturan tentang yayasan maka dibentuklah Undang-undang Nomor 16 Tahun 2001 tentang Yayasan (selanjutnya disebut Undang-undang Yayasan), yang pada tiga tahun kemudian direvisi melalui Undang-undang Republik Indonesia Nomor 28 Tahun 2004 tentang Perubahan Undangundang Republik Indonesia Nomor 16 Tahun 2001 tentang Yayasan (selanjutnya disebut Perubahan Undang-undang Yayasan).

Undang-undang yayasan bertujuan untuk memberikan pemahaman serta aturan yang benar kepada masyarakat mengenai yayasan, menjamin adanya kepastian hukum dan ketertiban hukum serta untuk mengembalikan landasan filosofis yayasan sebagai pranata hukum dalam rangka mencapai tujuan tertentu di bidang sosial, kemanusiaan dan keagamaan. Hal tersebut sebagaimana tercantum di dalam penjelasan dalam pembukaan Undang-undang Yayasan.

Terhadap pemberlakuan Undang-undang Yayasan tersebut, maka dapat dikatakan bahwa Yayasan telah diakui sebagai subyek hukum mandiri yang lepas dari kedudukan subyek hukum para pendiri atau pengurusnya, dimana Yayasan dapat menyandang hak dan kewajiban, dapat menjadi debitur maupun kreditur, sehingga dengan kata lain Yayasan dapat melakukan hubungan hukum apapun dengan pihak ketiga. Namun yayasan baru dapat dikatakan sebagai badan hukum bilamana pendiriannya telah melalui prosedur yang telah disyaratkan oleh Undang-undang Yayasan sebagaimana tercantum pada Bab II mengenai Pendirian, yaitu dibuat melalui akta pendirian dihadapan notaris, kemudian didaftarkan dan disahkan oleh Menteri Hukum dan Hak Asasi Manusia Republik Indonesia (Menkumham) ${ }^{5}$.

Sebagai salah satu bentuk yayasan, yayasan pendidikan yang ada di Indonesia sebagai penyelenggaraan pendidikanformal pada umumnya berbentuk badan hukum Yayasan, yang terikat dengan segala ketentuan sebagaimana yang tercantum dalam Undangundang Republik Indonesia Nomor 28 Tahun 2004 tentang Perubahan Undang-undang Republik Indonesia Nomor 16 Tahun2001 tentang Yayasandan Peraturan Pemerintah Republik Indonesia Nomor 63 Tahun 2008 jo. Peraturan Pemerintah Republik Indonesia Nomor 02 Tahun 2013 tentang Pelaksanaan Undang-undang tentang Yayasan.

Sebelum adanya pemberlakuan Undangundang Yayasan ini, yang oleh pendiri, pada awalnyaakanmendirikan lembaga pendidikan atau rumah sakituntuk tujuan komersial tidak mempunyai pilihan lain selain menggunakan yayasan sebagai badan hukum. Yayasan yang badan usahanya bergerak di lembaga

5 Rudhi Prasetya, Yayasan dalam Teori dan Praktik, Cetakan Pertama, (Jakarta: Sinar Grafika, 2012), hlm. 24. 
pendidikan, dalam pengelolaannya tidak sedikit yang menjurus kepada keuntungan belaka. Demikian pula halnya terhadap yayasan yang mengelola rumah sakit mewah maupun klinik-klinik persalinan, dan hal ini dianggap tidak sejalan dengan tujuan dari yayasan yang bersifat nirlaba.

Dengan berlakunya Undang-undang Yayasan ini, tidak sedikit rumah sakit yang pada awalnya berbentuk yayasan lalu merubah bentuk badan usahanya menjadi Perseroan Terbatas (PT), yang mana ketentuan tersebut telah diatur dalam Pasal 20 ayat (1) Undangundang Republik Indonesia Nomor 40 Tahun 2009 tentang Rumah Sakit yang berbunyi:

"Berdasarkan pengelolaannya Rumah Sakit dapat dibagi menjadi Rumah Sakit publik dan Rumah Sakitprivat".

dan Pasal 21 yang berbunyi:

"Rumah Sakit privat sebagaimana dimaksud dalam Pasal 20 ayat (1) dikelola oleh badan hukum dengan tujuanprofit yang berbentuk Perseroan Terbatas atau Persero".

Namun dalam pendirian lembaga sekolah swasta sampai detik ini belum ada aturan yang mengatur selain daripada tetap merujuk kepada yayasan sebagai badan hukumnya.

Terlepas dari pemberlakuan Undangundang Yayasan itu sendiri, keberadaannya sendiri hingga saat ini menimbulkan kritik dari berbagai kalangan, khususnya oleh organ yayasan, karena terdapat beberapa Pasal yang dianggap berbeda dengan praktek/pelaksanaan pengelolaan yayasan yang telah berlaku sebelum diundangkannya Undang-undang Yayasan tersebut, sehingga hal tersebut perlu dikaji lebih lanjut.
Salah satu Pasal yang berbeda dengan praktek yang telah dijalani selama ini adalah adanya pelarangan bagi organ yayasan untuk menerima gaji, upah atau honorarium dari yayasan sebagaimana yang termuat di dalam Pasal 5 Undang-undang Republik Indonesia Nomor 16 tahun 2001 tentang Yayasan yang menyatakan bahwa:

"Kekayaan Yayasan baik berupa uang, barang, maupun hasil kekayaan lain yang diperoleh Yayasan berdasarkan Undang-undang ini, dilarang untuk dialihkan atau dibagikan secara langsung atau tidak langsung kepada, Pengurus, Pengawas, karyawan, atau pihak lain yang mempunyai kepentingan terhadap Yayasan".

Ketentuan pidana terhadap pelanggaran tersebut diatur pada Pasal 70 Undang-undang Yayasan yang berbunyi:

1. "Setiap anggota dari organ Yayasan yang melanggar ketentuan sebagaimana yang dimaksud dalam Pasal 5, dipidana dengan pidana penjara paling lama 5(lima) tahun"; dan

2. "Selain dikenai pidana penjara, anggota organ yayasan sebagaimana dimaksud dalam ayat (1), juga dikenakan pidana tambahan" berupa kewajiban mengembalikan uang, barang, atau kekayaan yayasan yang dialihkan atau dibagikan."

Jika melihat ketentuan pada Pasal 5 tersebut di atas, maka akan berbanding terbalik dengan ketentuan pada Pasal 6 Undang-undang Yayasan dimana dalam Pasal tersebut menentukan bahwa:

"Yayasan wajib membayar segala biaya atau ongkos yang dikeluarkan oleh organ Yayasan dalam rangka menjalankan tugas Yayasan”. 
Pada ketentuan Pasal 6 tersebut, oleh organ yayasan dapat dijadikan sebagai sebuah peluang untuk melakukan penyimpangan hukum dikarenakan isi aturan tersebut bersifat abstrak dan multi tafsir.

Selain itu, besarnya tanggung jawab yang dipikul oleh pengurus yayasan juga harus menjadi pertimbangan ketika aturan ini dibuat, sebagaimana diatur dalam Pasal 35 ayat $(1)^{6}$ dan $(2)^{7}$ Undang-undang Yayasan. Dan jika aturan yang sedemikian ketatnya diberlakukan terhadap organ yayasan, khususnya terhadap pengurus yayasan, maka tidak akan ada yang mau menjadi pengurus suatu yayasan dikarenakan bekerja secara sukarela dan tidak akan memperoleh gaji, upah atau honorarium atas jerih payahnya mengurus suatu yayasan, atau akan dikenakan pidana penjara jika aturan tersebut dilanggar.

Aturan tersebut kemudian diubah dan dituangkan di dalam Pasal 5 UU No. 28 tahun 2004 tentang Perubahan UU No. 16 tahun 2001 tentang Yayasan, yang berbunyi:

1. "Kekayaan Yayasan baik berupa uang, barang, maupun kekayaan lain yang diperoleh Yayasan berdasarkan Undang-undang ini, dilarang dialihkan atau dibagikan secara langsung atau tidak langsung, baik dalam bentuk gaji, upah, maupun honorarium, atau bentuk lain yang dapat dinilai dengan uang kepada Pembina, pengurus dan Pengawas",

2. Pengecualian atas ketentuan yang dimaksud dalam ayat (1), wajib ditentukan dalam Anggaran dasar Yayasan bahwa Pengurus boleh menerima upah, gaji atau honorarium, dalam hal Pengurus dalam yayasan tersebut:

a. bukan termasuk pendiri Yayasan dan tidak terafiliasi ${ }^{9}$ baik itu dengan Pendiri, Pembina, maupun Pengawas; dan

b. melaksanakan kepengurusan Yayasan secara langsung dan penuh. $^{10}$

3. Penentuan mengenai gaji, upah, atau honorarium sebagaimana dimaksud pada ayat(2), ditetapkan oleh Pembina sesuai dengan kemampuan kekayaan Yayasan.»

Lagi-lagi perubahan tersebut tidak membawa angin segar terhadap organ yayasan, hal tersebut dikarenakan hanya pengurus, bukan Pembina dan pengawas, yang berhak memperoleh gaji/honorarium dengan beberapa pembatasan diantara pengurus tidak terafiliasi dengan Pendiri, Pembina maupun Pengawas yayasan, dan melaksanakan kepengurusan secara langsung dan penuh.

6 Bunyi lengkap Pasal 35 ayat (1):

Pengurus Yayasan bertanggung jawab penuh atas kepengurusan Yayasan untuk kepentingan dan tujuan Yayasan serta berhak mewakili Yayasan baik di dalam maupun di luar Pengadilan.

7 Bunyi lengkap Pasal 35 ayat (2):

Setiap Pengurus menjalankan tugas dengan itikad baik, dan penuh tanggung jawab untuk kepentingan dan tujuan Yayasan.

8 Penjelasan Pasal 5 ayat Undang-undang Yayasan:

Ketentuan dalam ayat ini dimaksudkan untuk menegaskan bahwa kekayaan Yayasan, termasuk hasil kegiatan usaha Yayasan, merupakan kekayaan Yayasan sepenuhnya untuk dipergunakan guna mencapai maksud dan tujuan Yayasan, sehingga seseorang yang menjadi anggota Pembina, Pengurus, dan Pengawas Yayasan bekerja secara sukarela tanpa menerima gaji, upah, atau honorarium.

9 Yang dimaksud dengan "terafiliasi" adalah hubungan keluarga karena perkawinan atau keturunan sampai derajat ketiga, baik secara horisontal maupun vertikal. 
Padahal seperti halnya Pengurus, yang mewajibkan yayasan untuk membayar Pembina dan Pengawas dalam suatu yayasan pendidikan juga mempunyai peran, fungsi dan tanggung jawab yang berkaitan erat terhadap kinerja Pengurus di dalam menjalankan operasional suatu yayasan sebagai satu kesatuan dalam melaksanakan tugas demi tercapainya tujuan yayasan. Jadi menurut penulis, wajar saja bilamana Pembina dan Pengawas menuntut hak yang sama terhadap bentuk diskriminasi yang terdapat di dalam aturan tersebut. Sehingga bilamana persoalan gaji maupun upah ini tidak segera dikaji oleh pemerintah, dikhawatirkan akan menimbulkan ketimpangan di dalam menjalankan roda operasional suatu yayasan.

Berdasarkan latar belakang tersebut, penulis melakukan penelitian menggunakan jenis penelitian empiris yaitu metode penelitian lapangan yang dilakukan di Yayasan Pendidikan Bina Utama Pontianak, untuk mendapatkan data primer dan menemukan kebenaran dengan menggunakan metode berpikir induktif dan kriterium berdasarkan kebenaran dari koresponden serta fakta yang ada dilapangan serta kajian melalui studi kepustakaan, maka kemudian penulis dapat merumuskan beberapa masalah yakni bagaimana implikasi adanya larangan gaji/ upah terhadap organ yayasanyang termuat dalam Pasal 5 ayat (1) Perubahan Undangundang Yayasan tersebut terhadap tata kelola yayasan pendidikan dan kemudian apakah aturan pada Pasal 6 Undang-undang Yayasan segala biaya/ ongkosyang telah dikeluarkan oleh organ yayasan dapat dijadikan sebagai peluang atas penerapan Pasal 5 Perubahan Undang-undang Yayasan tersebut.

\section{Pembahasan}

A. Dampak Atas Pemberlakuan Undang-undang Yayasan Khusus nya Pasal 5 Terhadap Tata Kelola Yayasan Pendidikan

\section{Eksistensi yayasan sebelum dan sesudah berlakunya Undang- undang yayasan}

Yayasan sebagai salah satu bentuk badan hukum di Indonesia telah ada jauh sebelum diberlakukannya Undang-undang Yayasan Nomor 16 Tahun 2001 pada tanggal 06 Agustus 2001. Dasar pengakuan yayasan sebagai badan hukum lebih didasarkan kepada kebiasaan, yurisprudensi dan doktrin para ahli hukum. Menurut pendapat Chaidir $\mathrm{Ali}^{11}$, yayasan menurut aturan kebiasaan dan yurisprudensi dapat dikatakan sebagai badan hukum bilamana telah memenuhi syarat materil dan syarat formil sebagai berikut:

1. Syarat Materil yang terdiri atas:

a. Adanya pemisahan harta kekayaan yang terpisah dari pendirinya,

b. Adanya tujuan tertentu,

c. Adanya alat perlengkapan (organisasi) yang teratur.

10 Penjelasan: melaksanakan tugas kepengurusan sesuai dengan ketentuan hari dan jam kerja Yayasan bukan bekerja paruh waktu (part time). 
2. Syarat Formil yang harus dipenuhi yaitu akta pendirian dibuat oleh Notaris (akta otentik).

Berdasarkan pada pandangan doktrin, yayasan sebagai badan hukum menurut pendapat para ahli seperti Meijers, Ali Rido, Suroso, dan Rudhi Prasetya menyimpulkan bahwa pada umumnya lebih menekankan pada adanya pemisahan kekayaan dan syarat organisasi, sekalipun dalam bentuk paling sederhana. Syarat lainnya yang mendapat perhatian dari para ahli yaitu adanya tujuan tertentu, tetapi Suroso tidak mencantumkan syarat tujuan ini, namun lebih menekankan pada pemisahan hak dan kewajiban para anggotanya.

Sementara untuk syarat formal, yaitu terhadap keharusan adanya akte tidak satupun dari para ahli yang mempersyaratkannya. Akibat dari ketiadaan aturan ini menimbulkan karagaman di dalam pendirian yayasan. Ada yang memiliki akta notaris, adapula yang melakukan pendaftaran di pengadilan negeri, bahkan ada yang mengumumkan diberita negara. Walaupun terjadi keragaman di dalam cara pendirian yayasan, serta saat penentuan status badan hukum, namun telah diakui bahwa yayasan adalah badan hukum, dan pendirian yayasan selalu dilakukan dengan akta notaris, baik yayasan yang didirikan oleh pihak swasta atau perorangan maupun oleh pemerintah.
Setelah berlakunya Undang-undang No. 16 Tahun 2001 tentang Yayasan, yang di dalamnya telah dicantumkan dengan jelas syarat pendirian yayasan untuk dapat dikatakan sebagai badan hukum. Adapun syarat-syarat tersebut adalah sebagai berikut ${ }^{12}$ : 1. Didirikan oleh 1 (satu) orang atau lebih,

2. Ada kekayaan dipisahkan dari kekayaan pendirinya,

3. Harus dilakukan dengan akta notaris dan dibuat dalam bahasa Indonesia,

4. Harus memperoleh pengesahan Menteri,

5. Diumumkan dalam tambahan berita negara republik Indonesia,

6. Tidak boleh memakai nama yang telah dipakai secara sah oleh yayasan lain, atau bertentangan dengan ketertiban umum/ atau kesusilaan,

7. Nama yayasan harus didahului dengan kata yayasan.

Dari uraian diatas dapat diketahui bahwa, baik sebelum maupun setelah berlakunya Undang-undang Yayasan, telah diakui bahwa Yayasan adalah badan hukum. Perbedaannya adalah sebelum berlakunya Udang-Undang Yayasanmasih terdapat keragaman tentang saat Yayasan menjadi badan hukum, tetapi setelah berlakunya Undang-undang Yayasan telah jelas bahwa Yayasan memperoleh status sebagai badan hukum pada saat mendapatkan pengesahan dari Menteri Hukum dan HakAsasi Manusia Republik Indonesia. Pengesahan dari

11 Chaidir Ali, Badan Hukum, (Jakarta: Alumni, 1987), hlm. 28.

12 Anwar Borahima, Kedudukan Yayasan di Indonesia, (Jakarta: Kencana, 2010), hlm. 16. 
Pemerintah (Menteri) ini merupakan syarat mutlak untuk diakui sebagai badan hukum.

\section{Analisis terhadap yayasan menurut Undang-undang Yayasan serta problematika di dalam penerapannya}

Yayasan merupakan salah satu bentuk dari perkumpulan yang berbadan hukum sebagaimana dinyatakan dalam Pasal 1 ayat (1) Undang-undang Nomor 16 Tahun 2001 tentang Yayasan yang berbunyi:

"Yayasan adalah badan hukum yang terdiri atas kekayaan yang dipisahkan dan diperuntukkan untukmencapai tujuan tertentu di bidang sosial, keagamaan, dan kemanusiaan, yang tidak mempunyai anggota”.

Jika kita kaji lebih lanjut, maka dapat diambil 4 (empat) unsur atas pengertian yayasan tersebut, yaitu 1.) yayasan sebagai badan hukum, 2.) mempunyai kekayaan yang terpisah, 3.) mempunyai tujuan tertentu, dan 4.) tidak mempunyai anggota selain organ di dalamnya. Selanjutnya akan penulis uraikan unsur-unsur tersebut sebagai berikut:

\section{Yayasan sebagai badan hukum}

Badan Hukum dalam bahasa Indonesia diartikan sebagai organisasi atau perkumpulan yang didirikan dengan akta yang otentik dan dalam hukum diperlakukan sebagai orang yang memiliki hak dan kewajiban atau disebut juga dengan subyek hukum.

Subyek hukum dalam ilmu hukum ada dua yakni, Natuurlijke Persoon (natural person) yaitu orang (Pasal 1329 KUHPerdata), dan
Rechtspersoon (legal entitle) yaitubadan usaha yang berbadan hukum (Pasal 1654 KUHPerdata). Disebut sebagai subyek hukum oleh karena orang dan badan hukum menyandang hak dan kewajiban hukum.

Secara umum badan hukum dapat dibedakan dalam dua jenis lagi, yaitu badan hukum publik dan badan privat. Kemudian badan hukum privat dapat dibagi menjadi 2 (dua) berdasarkan tujuan pendiriannya yaitu badan hukum privat yang bersifat profit/ mencari keuntungan (misalnya: Perseroan Terbatas, Koperasi) dan badan hukum privat yang bersifat nirlaba (misalnya: Yayasan, Perkumpulan).

Berdasarkan dari hasil penelitian di lapangan, salah satu permasalahan yang timbul adalah mengenai sosialisi terhadap pemberlakuan Undang-undang Yayasan memang sangat minim dilakukan oleh Pemerintah, hal tersebut mengakibatkan banyak yayasan yang mempertanyakan status yayasan yang telah didirikannya tersebut apakah masih dianggap sebagai badan hukum oleh Undang-undang yayasan, dan kekhawatiran tersebut memang beralasan dikarenakan masih banyaknya yayasan yang pada awal pendiriannya tidak melalui persyaratan sebagaimana yang telah ditentukan dalam Undang-undang Yayasan yaitu Yayasan telah didaftarkan di Pengadilan Negeri dan diumumkan dalam Tambahan Berita Negara Republik Indonesia, atau didaftarkan di Pengadilan Negeri dan mempunyai izin operasi dari instansi terkait. 
Namun oleh Pasal 71 Undang-undang Yayasan (Ketentuan Peralihan) diberikan jalan keluar atas permasalahan tersebut dimana dalam waktu paling lambat 5 (lima) tahun sejak berlakunya Undang-undang ini, Yayasan tersebut wajib menyesuaikan Anggaran Dasarnya dengan Undang-undang Yayasan. Setelah diadakan penyesuaian maka paling lambat 1 (satu) tahun harus sudah disampaikan keadaan tersebut kepada Menteri. Yayasan yang tidak menyesuaikan anggaran dasarnya, dapat dibubarkan (bukan bubar demi hukum) oleh Pengadilan atas permohonan Kejaksaan atau pihak yang berkepentingan. Dengan demikian Undang-undang Yayasan masih mengakui dan menerima Yayasan yang sudah ada sebelum diundangkannya undang-undang yayasan sebagai badan hukum asal telah memenuhi persyaratan sebagaimana yang ditetapkan oleh Pasal 71 ayat Undang-undang Yayasan. Selanjutnya melalui Perubahan Undang-undang Yayasan dalam Pasal 71 ditegaskan kembali bahwa yayasan dapat dikatakan sebagai badan hukum apabila telah memenuhi syarat-syarat yang telah ditentukan oleh Undang-undang Yayasan ini dan menambah masa 3 (Tiga) tahun bagi yayasan untuk melakukan penyesuaian Anggaran Dasar Yayasan terhitung sejak Undangundang ini mulai berlaku.

2. Yayasan mempunyai kekayaan yang terpisah

Kekayaan yayasan yang terpisah dari pendirinya merupakan syarat mutlak dari pembentukan yayasan sebagai badan hukum.
Adapun yang dimaksud kekayaan yayasan menurut Pasal 26 ayat (1) dan (2) Undangundang Yayasan yaitu kekayaan yang berasal dari sejumlah kekayaan yang dipisahkan dari pendirinya, baik dalam bentuk uang maupun barang.

Kekayaan yayasan dapat diperoleh dari sumbangan atau bantuan tidak mengikat, wakaf, hibah, hibah wasiat, maupun perolehan lain yang tidak bertentangan dengan Anggaran Dasar Yayasan dan/atau peraturan perundangundangan yang berlaku sebagaimana diatur pada Pasal 26 ayat (2) Undang-undang Yayasan.

Kekayaan tersebut merupakan modal awal bagi usaha yayasan yang berasal dari modal para pendiri dan kekayaan yang berasal dari sumber-sumber lainnya. Sesuai dengan tujuannya, maka kekayaan yayasan digunakan untuk mencapai tujuan tertentu di bidang sosial, keagamaan dan kemanusiaan, sehingga kegiatannya tidak hanya diperuntukkan dalam mencari keuntungan semata.

Dalam menjalankan kegiatannya, yayasan dituntut untuk mempunyai dana yang cukup guna mencapai tujuannya sehingga jika yayasan tidak mempunyai sumber penghasilan tetap maka dikhawatirkan akan menggangu jalannya kegiatan dan persoalan ini merupakan hal yang paling penting bagi yayasan. Berbeda halnya terhadap yayasan sosial yang sumber pendanaannya bergantung kepada adanya donatur, lantas bagaimana halnya terhadap yayasan pendidikan yang di dalamnya meliputi pembiayaan operasional 
baik terhadap sarana dan prasarana pendidikan maupun operasional terhadap kesejahteraan (gaji) para guru. Tanpa menyimpangi asas nirlaba, sebenarnya yayasan diperbolehkan untuk mencari keuntungan dengan cara mendirikan badan usaha maupun turut dalam penyertaan modal dalam sebuah perusahaan sebagaimana telah diatur dalam Pasal 3 ayat (1), dan Pasal 7 ayat (2) Undang-undang Yayasan $^{13}$.

3. Yayasan mempunyai tujuan tertentu

Yayasan merupakan lembaga yang idealis dengan kegiatannya yang mulia yaitu bergerak di bidang sosial, keagamaan, dan kemanusiaan.Sebagaimana layaknya sebuah organisasi, yayasan juga memiliki tujuan yang spesifik dan unik yang dapat bersifat kuantitatif maupun kualitatif. Tujuan yayasan yang bersifat kuantitatif mencakup pencapaian laba maksimum dan pertumbuhan organisasi. Sedangkan tujuan yayasan yang bersifat kualitatif dimaksudkan guna mencapai efisiensi dalam organisasi baik itu terhadap efektifitas organisasi maupun manajemen organisasi yang tangguh dengan menciptakan moral kerja tinggi (terhadap organ dan karyawan yayasan), serta demi mencapai pelayanan yang maksimal terhadap masyarakat sesuai dengan tujuan yayasan yang bergerak di bidang sosial, keagamaan dan kemanusiaan.
Sebagaimana halnya Yayasan Pendidikan Bina Utama Pontianak yang bergerak di bidang pendidikan, tentu saja tujuan yang ingin dicapai yaitu untuk ikut dan berperan serta di dalam membantu pemerintah mencerdaskan kehidupa berbangsa melalui pendidikan dan mencetak generasi yang cerdas yang berguna bagi masyarakat, bangsa dan Negara serta bagi kehidupan mereka di masa depan.

Tujuan merupakan hasil akhir terhadap semua proses yang akan dicapai oleh yayasan. Terhadap tujuan tersebut apakah telah sesuai atau tidak dengan sasaran yang ingin dicapai, tergantung atas kualitas sumber daya manusia di dalamnya serta kualitas kinerja para pelaku dalam yayasan tersebut dengan tidak mengesampingkan bahwa yayasan adalah sebagai badan hukum nirlaba, yang kegiatannya tidak diperuntukkan untuk mencari keuntungan semata ${ }^{14}$.

Di dalam mencapai tujuan ada beberapa faktor yang dapat digunakan sebagai pendorong/pemacu atas tercapainya suatu tujuan, salah satunya adalah dengan memperhatikan kesejahteraan para pelaksananya. Namun jika hal tersebut dikaitkan dengan aturan pada Pasal 5 Perubahan Undang-undang Yayasan maka bisa dipastikan bahwa tujuan suatu yayasan tidak akan dapat tercapai dikarenakan para

13 Bunyi lengkap Pasal 3 ayat (1) Undang-undang Yayasan:

"Yayasan dapat melakukan kegiatan usaha untuk menunjang pencapaian maksud dantujuannya dengan cara mendirikan badan usaha dan/atau ikut serta dalam suatu badan usaha".

Bunyi lengkap Pasal 7 ayat (2) Undang-undang Yayasan:

"Yayasan dapat melakukan penyertaan dalam berbagai bentuk usaha yang bersifat prospektifdengan ketentuan seluruh penyertaan tersebut paling banyak 25\% (dua puluh lima persen) dari seluruh nilai kekayaan Yayasan". 
pelakunya (organ) tidak dapat bekerja secara optimal akibat larangan yang termuat dalam Pasal 5 tersebut. Bukankah telah disebutkan diatas bahwa kesejahteraan/ penghargaan merupakan faktor pendorong utama dalam mencapai tujuan yang diinginkan.

4. Yayasan tidak mempunyai anggota selain organ di dalamnya

Yayasan tidak mengenal anggota selain daripada organ yang ada di dalam yayasan, yaitu Pembina, Pengurus dan Pengawas yayasan. Struktur organisasi dalam yayasan merupakan turunan dari fungsi, strategi dan tujuan organisasi dimana di dalamnya mencakup kompleksitas organisasi mulai dari Pimpinan (Pembina) yayasan yang sangat berpengaruh terhadap struktur organisasi termasuk pemilihan susunan anggota kepengurusan sampai kepada bentuk struktur birokrasi (pertanggungjawaban) yang diinginkan pada yayasan. Sedangkan fungsi badan hukum yayasan merupakan pranata hukum bagi pencapaian maksud dan tujuan tertentu di bidang sosial, keagamaan dan kemanusiaan.

Pola pertanggungjawaban yang berlaku di dalam kepengurusan suatu yayasan adalah Pengurus dan Pengawas bertanggung jawab kepada Pembina yayasan berupa hasil laporan kegiatan yang disampaikan dalam Rapat Pembina, yang diadakan setiap tahun sekali. Di sini dapat diambil kesimpulan bahwa Pembina merupakan kekuasaan tertinggi dalam struktur kepengurusan suatu yayasan.
Pola pertanggungjawaban di dalam yayasan bersifat vertikal dan horizontal, dimana pertanggung jawaban vertikal adalah pertanggungjawaban atas pengelolaan dana kepada otoritas yang lebih tinggi dan pertanggungjawaban manajemen yayasan kepada Pembina, yang mana keduanya merupakan elemen penting dalam menjaga kredibilitas suatu yayasan. Sedangkan pertanggungjawaban horizontal adalah pertangungjawaban yang ditujukan kepada masyarakat luas, dimana tujuan yayasan yang bersifat sosial, keagamaan dan kemanusiaan harus dapat lebih memberikan dampak yang positif di mata masyarakat dan menepis pandangan negatif yayasan sebagai lembaga yang mengeruk keuntungan semata.

\section{Analisis Pasal 5 perubahan undang-undang yayasan di tinjau dari konsep berfikir, teori keadilan dan peraturan perundang- undangan}

Berdasarkan ketentuan pada Pasal 5 Perubahan Undang-undang Yayasan yang secara tegas melarang atas kekayaan yayasan baik itu berupa uang, barang maupun kekayaan lain untuk dialihkan atau dibagikan dalam bentuk gaji, upah, honorarium atau bentuk lain yang dapat dinilai dengan uang kepada Pembina, Pengurus, dan Pengawas pada dasarnya sebagai bentuk antisipasi terhadap segala bentuk penyimpangan yang kerap 
terjadi di dalam pengelolaan suatu yayasan di Indonesia, khususnya terhadap pengelolaan kekayaan/ keuangan yayasan yang berakibat banyaknya kasus yayasan yang timbul berkenaan dengan penyalahgunaan wewenang pengurus di dalam penggunaan dana yayasan.

1. Analisis terhadap larangan pada pasal

5 Perubahan Undang-undang Yayasan melalui konsep berfikir

Jika dianalisis secara logika berfikir, Pendiri selaku pengusaha yang menggunakan yayasan sebagai bentuk usahanya tentunya berharap untuk memperoleh keuntungan di dalam usahanya tersebut, sehingga dengan adanya larangan pembagian keuntungan dalam bentuk apapun terhadap hasil usaha yayasan tersebut artinya buat apa mereka mendirikan yayasan, bukankah keuntungan tersebut merupakan tujuan mereka dalam menjalankan suatu usaha.

Padahal seperti yang kita ketahui, sekolah sebagai lembaga pendidikan dalam perkembangannya dianggap sebagai ladang bisnis yang sangat berpotensi dalam mengeruk keuntungan. Lembaga pendidikan swasta berlomba-lomba dalam memberikan fasilitas pendidikan yang sebaik mungkin bagi anak didik mulai dari tingkat pra-sekolah sampai dengan tingkat pendidikan tinggi dengan sarana dan prasara yang bisa dibilang tidak murah. Hal tersebut tentu saja menuntut biaya yang tidak sedikit terhadap biaya pendidikan anak didik sehingga muncul istilah sekolah atau kampus elit oleh masyarakat. Dengan tingginya biaya pendidikan yang telah dikeluarkan oleh orang tua anak didik tentu saja hasil yang diharapkan adalah anak didik dapat memperoleh pendidikan yang bagus demi bekal mereka di masa depan.

Yayasan sebagai badan yang menaungi sekolah sejatinya harus tetap ada/eksis demi keberlangsungan kegiatan belajar mengajar di sekolah tersebut. Apalagi dengan semakin bagusnya pendidikan di sekolah negeri ditambah perluasan lokal kelas dan banyaknya sekolah swasta yang berdiri, mengakibatkan tingginya persaingan di dalam memperoleh siswa. Mengantisipasi hal tersebut mau tidak mau menuntut yayasan untuk melakukan perbaikan dari segala sisi baik itu peningkatan terhadap kualitas tenaga pengajar maupun perbaikan dan kelengkapan sarana sekolah. Di sinilah letak peran organ yayasan dalam melihat hal tersebut apakah sebagai sebuah tantangan ataukah sebuah halangan. Segala macam resiko yang bakal dihadapi oleh yayasan membuat organ di dalamnya harus bekerja keras guna mencari jalan keluar terhadap segala resiko yang bakal dihadapi nantinya. Jadi kesimpulan yang dapat ditarik adalah peran guru selaku tenaga pendidik di sekolah swasta tetap bergantung kepada eksistensi yayasan sebagai badan yang menaungi sekolah tersebut, dan peran organ yayasan-lah yang dengan segala strategi untuk membuat yayasan tersebut tetap eksis dan survive walaupun keberadaannya semakin terhimpit oleh keberadaan sekolah negeri yang semakin bagus dan berkualitas. 
Larangan pemberian gaji, upah atau honorarium kepada Pembina, Pengurus dan Pengawas yayasan akan menimbulkan efek terhadap kinerja para organ di dalamnya. Jika terhadap ketentuan pada Pasal 5 ayat (2) Perubahan Undang-undang Yayasan yang menyatakan bahwa pengecualian pemberian imbalan berupa gaji atau upah hanya kepada Pengurus yayasan maka terhadap Pembina dan Pengawas yang tidak mendapat imbalan, tidak akan ada lagi orang yang mau mendirikan yayasan, tidak ada yang mau menjadi Pembina dan Pengawas yayasan, dan tentunya ini akan berakibat pada berkurangnya lembaga yang berbentuk yayasan. Secara umum ini akan merugikan fakir miskin, anak-anak terlantar dan masyarakat umum yang selama ini menjadi penerima manfaat dari aktivitas sebuah yayasan, dan secara khusus berimbas kepada semakin berkurangnya lembaga pendidikan swasta yang bernaung kepada yayasan sehingga ada besar kemungkinan cita-cita luhur bangsa Indonesia sebagaimana yang diamanatkan UUD 1945 akan semakin sulit untuk diwujudkan dalam mencerdaskan kehidupan bangsa.

Sehingga pada akhirnya dapat disimpulkan bahwa pada dasarnya maksud dari adanya larangan tersebut oleh Perubahan Undangundang Yayasan adalah kegiatan usaha Yayasan bukan ditujukan untuk kepentingan pengurusnya, melainkan tetap dipergunakan untuk kepentingan umum. Jadi penekanannya bukan pada keuntungan (profit) melainkan pada kemanfaatan (benefit).
2. Analisis yuridis terhadap larangan pada Pasal 5 Perubahan Undang-undang Yayasan

Terhadap pengertian yayasan yang termuat dalam Pasal 5 Perubahan Undang-undang Yayasan, unsur penting yang dapat ditarik dalam ketentuan pada Pasal 5 ini ialah adanya larangan berupa gaji/upah atau bentuk lain yang dapat dinilai dengan uang.

Larangan secara harfiah dapat diartikan sebagai keharusan bagi seseorang untuk tidak berbuat sesuatu oleh karena akibatakibatnya dipandang tidak baik baik bagi pelaku maupun terhadap orang lain. Tujuan adanya larangan dalam kaidah hukum adalah untuk menciptakan keseimbangan antara kepentingan subjek hukum satu dengan subjek hukum yang lain, untuk mengatur perbuatan manusia yang bersifat lahiriah dengan adanya sanksi yang tegas dan bertingkat, serta untuk menciptakan kedamaian (ketertiban dan ketentraman) dalam masyarakat.

Berbicara mengenai gaji/ upah, maka akan bersinggungan dengan peraturan yang termuat dalam Undang-undang Ketenakerjaan. Gaji atau upah menurut Pasal 1 ayat 30 Undangundang Republik Indonesia Nomor 13 Tahun 2003 tentang Ketenagakerjaan adalah:

"hak pekerja/buruh yang diterima dan dinyatakan dalam bentuk uang sebagai imbalan dari pengusaha atau pemberi kerja kepada pekerja/buruh yang ditetapkan dan dibayarkan menurut suatu perjanjian kerja, kesepakatan, atau peraturan perundang-undangan, termasuk tunjangan bagi pekerja/buruh dan keluarganya atas suatu pekerjaan 
dan/atau jasa yang telah atau akan dilakukan".

Dikatakan bahwa gaji atau upah adalah HAK bagi pekerja setelah melaksanakan KEWAJIBAN-nya di dalam melakukan suatu pekerjaan, sehingga pemberian upah merupakan suatu imbalan, balas jasa atau bentuk perhargaan dari perusahaan kepada tenaga kerjanya atas prestasi dan jasa yang disumbangkan dalam kegiatan produksi.

Apabila larangan tersebut diterapkan untuk yayasan pendidikan, maka larangan tersebut akan menjadi sebuah hambatan di dalam penerapan dunia pendidikan karena seperti yang telah diuraikan diatas, kualitas pendidikan yang baik harus didukung oleh tenaga pengajar yang baik juga serta sarana prasarana yang memadai dan hal tersebut tentu saja membutuhkan dana yang tidak sedikit. Berbeda halnya terhadap sekolah negeri yang segala biaya operasional dan sarana prasarananya ditunjang oleh Pemerintah, terhadap sekolah swasta hal tersebut menjadi tanggung jawab yayasan sebagai badan yang mengelola sekolah swasta. Apalagi di yayasan pendidikan biasanya organ yayasan juga merupakan tenaga pendidik di sekolah tersebut sehingga yang terjadi adalah berbagai penafsiran yang timbul bila ia menerima upah sebagai tenaga pengajar apakah itu dapat disamakan dengan menerima manfaat atas hasil yayasan.

Jika teori keadilan distributif ini penulis gunakan sebagai teoridasar analisis makasudah barang tentu adanya larangan pemberian gaji atau upah terhadap organ yayasan, khususnya terhadap Pembina dan Pengawas yayasan, dapat dikatakan sebagai bentuk ketidakadilan dimana terhadap Pengurus, yang walaupun dengan beberapa batasan, berhak memperoleh gaji namun hal tersebut tidak berlaku bagi Pembina dan Pengawas yang sama-sama bekerja dan berusaha di dalam mengelola yayasan. Kesejahteraan merupakan faktor pendorong terhadap suatu keberhasilan karena dengan semakin besar manfaat yang diterima, maka semakin besar pula beban dan tanggung jawab yang harus dipikul oleh organ yayasan. Sekali lagi, besarnya manfaat yang diterima tentu saja disesuaikan dengan besarnya beban dan tanggung jawab yang diemban oleh masing-masing organ dan disesuaikan dengan kemampuan keuangan yayasan, dan atas manfaat tersebut tidak serta merta dijadikan sebagai patokan berhasil atau tidaknya usaha yang dijalankan, namun hal tersebut diberikan sebagai bentuk penghargaan atas usaha dan kerja yang telah dilakukan demi mencapai maksud dan tujuan yayasan.

Terhadap adanya larangan tersebut jika dikaji melalui analisis yuridis, pada dasarnya bertentangan dengan konstitusi sebagaimana yang diamanatkan di dalam Undang-Undang Dasar Republik Indonesia Tahun 1945 (UUD 1945) khususnya pada Pasal 27 ayat (2), Pasal 28D ayat (2) dan Pasal 28I ayat (2) yang di dalamnya memuat asas keadilan dan asas persamaan hak bagi warga negara. Di dalam Pasal 27 ayat (2) dan Pasal 28D ayat (2) UUD 1945 dikatakan bahwa: 
"Tiap-tiap warga Negara berhak atas pekerjaan dan penghidupan yang layak bagi kemanusiaan" dan

"setiap orang berhak untuk bekerja serta mendapat imbalan dan perlakuan yang adil dan layak dalam hubungan kerja".

Sehingga jika kita kaitkan 2 (dua) Pasal tersebut diatas dengan ketentuan Pasal 5 Perubahan Undang-undang Yayasan maka dapat dikatakan bahwasanya larangan tersebut sudah bertentangan dengan apa yang diamanatkan oleh UUD 1945, mengekang kebebasan warga negara untuk memperoleh penghidupan yang layak, karena UUD 1945 telah menjamin hak setiap warga negara untuk memperoleh pekerjaan dan mendapatkan imbalan atas pekerjaannya tersebut. Selain itu demi melengkapi nilai keadilan terhadap adanya larangan dalam Pasal 5 Perubahan Undang-undang Yayasan tersebut, maka penulis merujuk pada ketentuan dalam Pasal 28 I ayat (2) UUD 1945 yang menyatakan bahwa:

"setiap orang bebas dari perlakuan yang bersifat diskriminatif atas dasar apapun dan berhak mendapat perlindungan terhadap perlakuan yang bersifat diskriminatif itu".

Sehingga dengan demikian dapat ditarik sebuah kesimpulan bahwa penerapan Pasal 5 Perubahan Undang-undang Yayasan bertentangan terhadap konstitusi dan tidak memenuhi unsur keadilan sebagaimana diamanatkan oleh UUD 1945, dan di dalam penerapannya di lapangan dirasa tidak efektif karena jika aturan tersebut diterapkan maka akan menimbulkan kekhawatiran bagi pelaku/ organ yayasan (terhadap ancaman pidana) untuk menerima dan memperoleh manfaat atas hasil usaha yang dikelola dalam yayasan tersebut.

\section{B. Penggunaan Pasal 6 Undang- undang Yayasan guna mencari celah hukum atas pengenaan Pasal 5 Undang-undang Yayasan}

Adanya larangan gaji/upah terhadap organ yayasan tersebut pada Pasal 5 Perubahan Undang-undang Yayasan merupakan suatu "pukulan" bagi mereka dimana sebelum berlakunya Undang-undang Yayasan ini mereka masih bebas untuk mengelola dana yayasan termasuk memperoleh manfaat atas hasil usaha yayasan. Namun dalam praktek keseharian, penerapan terhadap larangan tersebut masih dapat dikatakan belum tercapai secara maksimal dikarenakan kontrol/ pengawasan dari luar terhadap yayasan nyaris tidak ada. Kelemahan inilah yang kerap kali digunakan oleh organ yayasan, khususnya Pengurus untuk melakukan penyelewengan dana yayasan yang seyogyanya digunakan untuk mencapai tujuan yayasan malah digunakan untuk kepentingan Pengurus yayasan.

Disadari atau tidak, aturan pada Pasal 6 Undang-undang Yayasan sebenarnya dapat digunakan sebagai tameng atas larangan yang termuat pada Pasal 5 Perubahan Undangundang Yayasan, dimana pada Pasal 6 Undang-undang Yayasan disebutkan bahwa:

"Yayasan wajib membayar segala biaya atau ongkos yang dikeluarkan oleh organ 
Yayasan dalam rangka menjalankan tugas Yayasan".

Secara logika, yang dapat penulis tangkap atas maksud dari Pasal ini adalah kewajiban yayasan untuk mengganti segala biaya atau ongkos yang telah dikeluarkan oleh organ yayasan dari kantongnya sendiri (uang pribadi) dengan menunjukkan bukti-bukti pengeluaran.

Bagi organ yayasan ketentuan dalam Pasal 6 ini justru dianggap menguntungkan bagi mereka karena walaupun ada larangan bagi mereka untuk memperoleh gaji/upah, namun dengan adanya kewajiban yayasan untuk mengganti terhadap biaya atau ongkos tersebut dianggap sebagai jalan keluar untuk memperoleh manfaat atas usaha mereka mengelola yayasan. Sepanjang tidak ada sanksi yang mengatur dan tidak dijelaskan lebih lanjut baik dalam Undang-undang maupun Peraturan Pelaksana, maka hal tersebut dianggap sah secara hukum. Di sini dapat dikatakan bahwa telah terjadi kekaburan hukum yang mana atas satu orang dengan orang yang dapat menfasirkannya secara berbeda-beda. Kekaburan hukum dalam suatu undang-undang cenderung mempengaruhi sikap dan kuantitas ketidakpatuhan serta mempunyai efek nyata terhadap perilaku hukum, termasuk perilaku pelanggar hukum. Kondisi ini akan mempengaruhi penegakan hukum yang menjamin kepastian dan keadilan dalam masyarakat.

Penggunaan Pasal 6 Undang-undang Yayasan sebagai peluang oleh organ yayasan untuk menikmati manfaat atas hasil usaha yayasan juga tidak sepenuhnya dapat dibenarkan. Seharusnya Undang-undang Yayasan memberikan penjelasan mengenai apa yang dimaksud dalam Pasal 6 tersebut, seperti biaya atau ongkos yang dikeluarkan oleh organ dalam rangka menjalankan tugas yayasan. Sebagai contoh apakah biaya transportasi atau biaya pulsa telepon genggam yang telah dikeluarkan oleh organ yayasan yang digunakan untuk juga termasuk dalam kategori menjalankan tugas yayasan, jika hal tersebut dibenarkan, maka hal tersebut tidak ada bedanya dengan upah atau gaji bagi organ yayasan, hanya saja menggunakan istilah yang berbeda. Secara otomatis akan mengakibatkan membengkaknya pos-pos pengeluaran pada yayasan walaupun hal tersebut dapat dibuktikan dengan kwitansi atau bon pembayaran fiktif. Jika penafsiran tersebut yang digunakan, maka jelas mengandung kekaburan hukum yang dapat disalah gunakan, sehingga jauh dari apa yang diinginkan oleh Undang-undang Yayasan yang menuntut adanya transparansi dalam pengelolaan kekayaan yayasan. Namun sekali lagi, hal tersebut dapat terjadi dikarenakan lemahnya pengawasan terhadap yayasan dari luar. Pengawasan dari luar hanya dapat dilakukan bilamana organ yayasan melakukan perbuatan melawan hukum atau bertentangan dengan Anggaran Dasar Yayasan, lalai dalam melaksanakan tugasnya, melakukan perbuatan yang merugikan yayasan atau pihak ketiga atau Negara. Pemeriksaan juga hanya dapat 
dilakukan bilamana ada penetapan Pengadilan atas permohonan pihak ketiga yang merasa dirugikan disertai alasan, atau atas permintaan Kejaksaan bilamana telah merugikan Negara.

\section{Simpulan}

Adanya larangan bagi organ yayasan khususnya Pembina dan Pengawas dalam memperoleh gaji/upah sebagaimana dimaksud dalam Pasal 5 Perubahan Undang-undang Yayasan dalam penerapannya di keseharian dianggap tidak efektif dan bertolak belakang dengan kebiasaan yang telah dilakukan selama ini. Di lain sisi jika dilakukan kajian secara yuridis maka adanya larangan tersebut bertentangan dengan konstitusi sebagaimana diamanatkan dalam UUD 1945 dimana setiap warga negara berhak untuk memperoleh pekerjaan dan memperoleh penghasilan demi penghidupan yang layak, sehingga dengan adanya larangan tersebut hak-hak warga negara untuk memperoleh penghidupan dan pekerjaan yang layak tidak dapat terpenuhi karena adanya sanksi pidana bila larangan tersebut dilanggar.

Pada Pasal 6 Undang-undang Yayasan yang mengatur kewajiban yayasan untuk membayar segala ongkos atau biaya yang telah dikeluarkan organ dalam menjalankan tugas yayasan, oleh organ yayasan dapat dijadikan peluang di dalam memperoleh manfaat atas hasil usaha yayasan. Hal tersebut karena adanya kekaburan hukum (ketidak pastian) yang berakibat timbulnya penafsiran yang berbeda-beda terhadap maksud dan tujuan Pasal 6 tersebut. Idealnya maksud dan tujuan pada Pasal 6 tersebut adalah yayasan memberikan penggantian atas biaya yang telah dikeluarkan oleh organ dari uang pribadinya. Namun karena tidak memuat penjelasan, maka dianggap "segala biaya" yang telah dikeluarkan berhak memperoleh pengantian oleh yayasan, sehingga dengan memberikan bukti fiktif pun hal tersebut dianggap sah menurut hukum.

\section{DAFTAR PUSTAKA}

\section{Buku}

Ali, Chaidir. Badan Hukum. Jakarta: Alumni, 1987.

Bastian, Indra. Akuntansi Yayasan dan Lembaga Publik. Jakarta: Erlangga, 2007.

Borahima, Anwar. Kedudukan Yayasan di Indonesia. Jakarta: Kencana, 2010.
Harsono, Boedi. Hukum Agraria Indonesia, Sejarah Pembentukan Undang-undang PokokAgraria, Isidan Pelaksanaannya, Jilid I Hukum Tanah Nasional. Jakarta: Djambatan, 1994.

Otto, Jan Michael. Kepastian Hukum di Negara Berkembang. Terjemahan oleh Tristam Moeliono, Jakarta: Komisi Hukum Nasional, 2003. 
Prasetya, Rudhi. Yayasan dalam Teori dan Praktik. Cetakan Pertama. Jakarta: Sinar Grafika, 2012.

Setiadi, A. Dana Pensiun Sebagai Badan Hukum. Bandung: Citra Aditya Bakti, 1995.

\section{Peraturan Perundang-undangan}

Undang-undang Dasar Republik Indonesia Tahun 1945 (amandemen ke-empat).

Undang-undang Republik Indonesia Nomor 16 Tahun 2001 tentang Yayasan.

Undang-undang Republik Indonesia Nomor 28 Tahun 2004 tentang Perubahan
Undang-undang No. 16 Tahun 2001 tentang Yayasan.

Undang-undang Republik Indonesia Nomor 7 Tahun 1983 tentang Pajak Penghasilan $(P P h)$.

Undang-undang Republik Indonesia Nomor 13 Tahun 2003 tentang Ketenagakerjaan.

Undang-undang Republik Indonesia Nomor 40 Tahun 2009 tentang Rumah Sakit.

Peraturan Pemerintah Republik Indonesia Nomor 63 tahun 2008 tentang Yayasan.

Peraturan Pemerintah Republik Indonesia Nomor 2 Tahun 2013 tentang Perubahan Terhadap PP Nomor 63 Tahun 2008 tentang Yayasan. 